\title{
PEMBERDAYAAN MASYARAKAT DESA DENGAN PEMBUATAN KERAMBA JARING APUNG (KJA) UNTUK BUDIDAYA IKAN TAWAR DI EMBUNG DESA BANARAN, KLATEN
}

\author{
Bambang Setiawan ${ }^{1}$, Yusep Muslih Purwana ${ }^{1}$, Noegroho Djarwanti ${ }^{1}$, \\ Niken Silmi Surjandari ${ }^{1}$, Siti Nurlita Fitri ${ }^{1 *}$ \\ ${ }^{1}$ Universitas Sebelas Maret, Surakarta, Indonesia \\ *sitinurlitafitri@staff.uns.ac.id
}

\begin{abstract}
Abstrak: Desa Banaran terletak di Kecamatan Delanggu, Kabupaten Klaten, Jawa Tengah. Desa ini mempunyai embung desa yang belum dimanfaatkan secara produktif oleh masyarakat setempat. Masyarakat telah mengelola embung tersebut untuk budidaya ikan, namun usaha tersebut belum membuahkan hasil optimal karena prosedur pembenihan dan proses panen yang belum tepat. Akibatnya, keberadaan embung desa tersebut belum memberikan kontribusi yang signifikan untuk peningkatan ekonomi masyarakat. Oleh karenanya dibutuhkan suatu upaya pemberdayaan untuk meningkatkan kualitas ekonomi masyarakat dengan memanfaatkan embung desa secara tepat. Tujuan dari kegiatan pengabdian ini adalah pemberdayaan masyarakat dengan melakukan pemanfaatan embung Desa Banaran dengan pembuatan keramba jaring apung (KJA) sebagai bentuk kegiatan budidaya ikan tawar. Kegiatan ini dimulai dengan survei awal potensi dan pengukuran untuk membuat desain $\mathrm{KJA}$. KJA didesain dengan menggunakan baja ringan dengan pemanfaatan drum besar untuk penyangga. Benih ikan yang dimasukan ke dalam keramba yaitu benih ikan nila. Selain itu, dilakukan juga sosialisasi kepada masyarakat atas kegiatan pemberdayaan budidaya ikan. Hasil dari pengabdian masyarakat ini adalah transfer ilmu budidaya ikan tawar dengan $\mathrm{KJA}$ beserta bantuan alat keramba dan benih kepada warga Desa Banaran. Dari data awal penebaran benih ikan, kematian banyak terjadi di awal fase kemudian mengalami penurunan dan mulai stabil pada minggu ke 6. Hasil panen ikan tawar dari kegiatan ini juga dapat menjadi sumber pangan dan pendapatan masyarakat Desa Banaran. Diharapkan kegiatan ini dapat menjadi langkah awal untuk kegiatan pemberdayaan masyarakat lainnya diwaktu yang akan datang.
\end{abstract}

Kata Kunci: embung, ikan tawar, keramba jaring apung (KJA)

\begin{abstract}
Banaran is a village located in Delanggu, Klaten-Central Java. This area has an unproductive reservoir yet by the resident. The resident has been managing the reservoir to fish cultivation, but then the action is not enough successful because of the lack of the correct procedure. This has not made a significant impact on the community's economy, thus efforts to empower the community are needed to improve the reservoir's economic quality. The purpose of this program is community empowerment to design and installs the new product; a floating net cage to fish farming of Banaran reservoir. The first stage of this study was survey and interview in the reservoir location. The next stage was designing the net floating cage in the detailed draft. KJA was designed using mild steel with the use of a large drum for support. Fish seeds that are put into cages are tilapia seeds. In addition, socialization was also carried out to the community on fish farming empowerment activities. The result of this community service is a transfer of knowledge of fish cultivation with KJA along with the assistance of cages and seeds to the residents of Banaran Village. The number of fish deaths decreased and began to stabilize at the 6th week. Fish harvests from this project can also be a source of food and income for the people of Banaran Village. Hopely, this activity can be a starting point for other community empowerment activities in the future.
\end{abstract}

Keywords: reservoir, freshwater fish, floating net cage

\section{Pendahuluan}

Embung merupakan suatu cekungan yang biasanya digunakan untuk menampung air 
permukaan beserta air hujan pada area sekitar embung dengan luas tidak terlalu besar. Menurut Rustam (2010), definisi dari embung merupakan bangunan buatan yang digunakan untuk menampung dan menyimpan air pada volume yang tidak terlalu besar, yaitu lebih sedikit dari kapasitas volume waduk. Pembangunan embung disuatu daerah dilakukan dengan cara pembendungan suatu sungai kecil atau bisa juga dibangun diluar sungai. Dangnga, Halimah, \& Asniar (2019) mengatakan jika pemanfaatan embung biasanya digunakan untuk penyimpanan air untuk seluruh warga desa pada saat kemarau dengan prioritas utama yaitu warga, ternak, dan terkahir adalah untuk pertanian. Selain itu, menurut Rahman, Nursari, \& Baskoro (2019), embung juga merupakan salah satu metode konservasi air dan tanah dengan tujuan untuk meningkatkan inflitrasi dan retensi air permukaan, serta mengurangi aliran permukaan. Lebih dari itu, kapasitas volume embung ditentukan dari kapasitas kebutuhan air yang harus mempertimbangkan aspek kehilangan air akibat penguapan (Rahmadana 2013).

Pemanfaatan embung selain dari potensi penyimpanan air untuk makhluk hidup, yaitu digunakan juga untuk budidaya ikan air tawar. Ikan tawar yang dibudidayakan pada suatu embung dapat memberikan sumbangsih besar pada perkembangan ekonomi suatu daerah apabila dikelola dengan baik. Menurut Ardi (2013), pengelolaan budidaya yang terkendali memberikan dampak positif bagi lingkungan yang salah satunya adalah dengan penggunaan Keramba Jaring Apung (KJA).

Embung Desa Banaran Kecamata Delanggu Kabupaten Klaten belum digunakan secara menyeluruh bagi warga desa. Selama ini, pemanfaatan yang dilakukan hanya sebagai tempat budi daya ikan dengan cara yang belum optimal. Benih ikan disebarkan langsung pada permukaan air dalam bendung. Ikan tidak dikontrol perkembangannya dan dibiarkan hidup secara alami. Setelah tiba waktunya, ikan kemudian dipanen dengan cara dipancing. Berangkat dari masalah tersebut, diperlukan suatu upaya melalui kegiatan untuk mengoptimalkan pemanfaatan embung desa dengan budidaya ikan tawar. Tujuan utama dari kegiatan ini adalah untuk meningkatkan kemajuan ekonomi warga setempat. Menurut Hidayati, Darsono, \& Barokah (2020), penggunaan KJA untuk budidaya ikan tawar pada Waduk Kedung Ombo dapat menghasilkan nilai efisiensi usaha sebesar 1,3. Lokasi embung Desa Banaran diberikan pada Gambar 1.

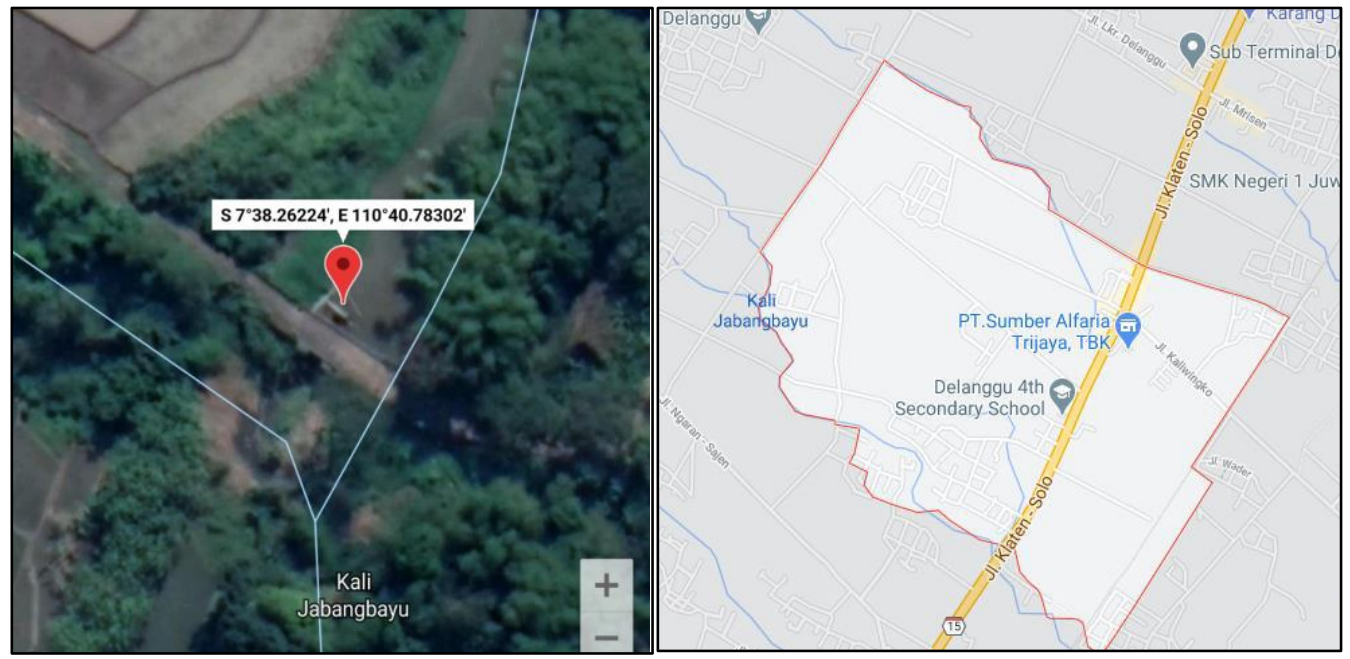

Gambar 1. Lokasi Embung Desa Banaran 
Dari beberapa analisis situasi di atas, maka tujuan dilakukannya pengabdian masyarakat dengan upaya pemanfaatan embung desa melalui pembuatan $\mathrm{KJA}$ adalah untuk memberikan sarana kepada masyarakat setempat bagaimana cara dalam memelihara embung dan sistem tata kelola sumber daya air dengan baik dan benar. Selain itu, dilakukan stimulan berupa pemberian paket budidaya ikan air tawar dalam keramba terapung $(K J A)$, yang terdiri dari fisik rangkaian keramba, benih ikan siap pelihara, pakan ikan berupa pelet dan kegiatan penyuluhan tentang budidaya ikan dalam keramba dan pemeliharaan embung.

\section{Metode}

Kegiatan pengabdian masyarkarat melalui pemanfaatan embung desa menggunakan KJA bagi masyarakat Desa Banaran, Klaten dilakukan dengan metode pendekatan Community development sebagaimana pada Gambar 2. Gambar 2 menjelaskan beberapa tahapan metode yang digunakan untuk kegiatan pengabdian. Metode yang digunakan yang pertama adalah proses survei. Proses survei digunakan untuk memastikan potensi embung yang akan dilakukan pemanfaatan, selain itu dilakukan pengukuran lebar embung dan perkiraan tata letak KJA. Sebagai tambahan, dilakukan proses wawancara pada masyarakat sekitar untuk memastikan kegiatan yang selama ini telah dilakukan di daerah embung, memastikan kegiatan ini cocok dengan perilaku dan keinginan masyarakat setempat dan penyatuan visi serta misi dari pihak tim pengabdian dengan masyarakat Desa Banaran.

\section{Survei dan wawancara}

Memahami permasalahan pada mitra dan kegiatan yang sesuai untuk penanggulangannya

Hasilnya: Embung desa belum termanfaatkan dengan baik untuk budidaya ikan tawar

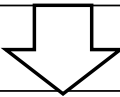

\section{Penentuan metode kegiatan}

Pembuatan keramba jaring apung $(\mathrm{KJA})$ untuk budidaya ikan tawar, pemberian benih ikan dan pakan serta kegiatan penyuluhan

\section{Pelaksanaan kegiatan}

Survei lokasi embung, desain $\mathrm{KJA}$, instalasi $\mathrm{KJA}$, penyebaran benih, dan sosialisasi kepada masyarakat Desa Banaran, Klaten.

Gambar 2. Kerangka Pemecahan Masalah

Dari hasil wawancara dan survei lokasi dilakukanlah desain dari KJA yang akan digunakan. Ukuran dan letak KJA harus bisa diterapkan dan dipikirkan kemudahan instal perangkatnya. Kemudian dilakukan perhitungan kebutuhan bahan habis pakai yaitu baja ringan dan drum sebagai pengapung dari KJA. Selain itu juga dilakukan perhitungan jumlah benih yang akan disebar pada KJA yang sudah direncanakan disertai perhitungan kebutuhan jumlah pakan. Di 
harapkan perhitungan jumlah pakan sesuai dengan kondisi keberlangsungan perkembangan benih hingga ikan dapat dipanen sesuai dengan berat yang direncanakan. Untuk itu dilakukan monitoring berkelanjutan setiap hari dengan cara menimbang berat benih ikan disertai pemberian makan dan pembersihan daerah sekitar KJA. Proses selanjutnya yaitu memberikan penyuluhan kepada masyarakat Desa Banaran tentang pemanfaaatan embung untuk budidaya ikan dengan $\mathrm{KJA}$.

\section{Hasil dan Pembahasan}

\section{Survei Lokasi}

Kegiatan survei dimulai pada awal tahun 2021 dalam rangka melihat dan mengkaji secara visual potensi untuk pemanfaatan bendung. Kegiatan ini didokumentasikan pada Gambar 3.

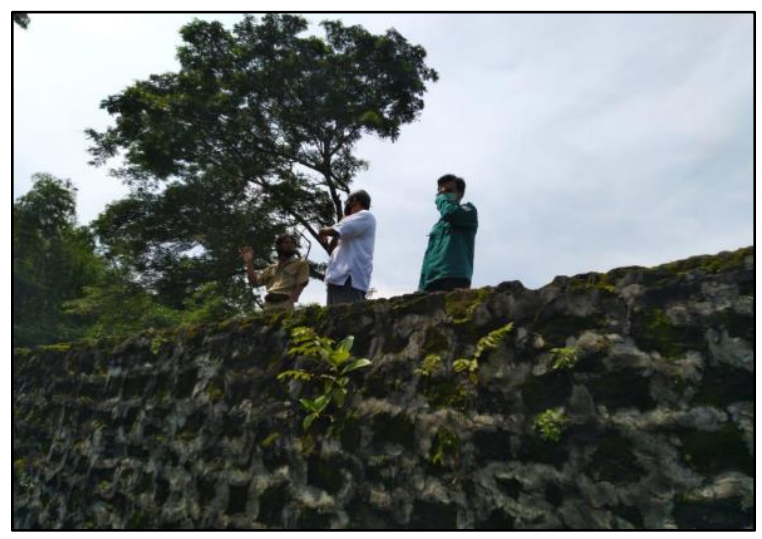

(a)

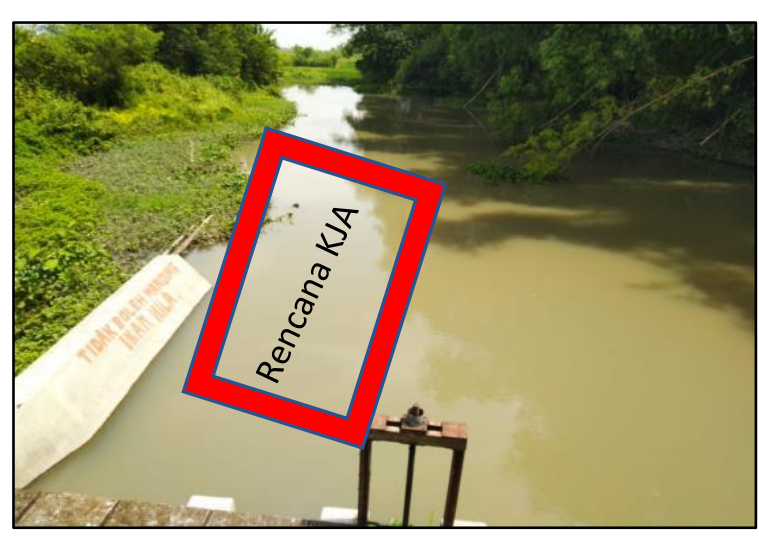

(b)

Gambar 3. (a) Survei lokasi dari atas embung; (b) Tampak embung Desa Banaran

Gambar 3 (a) merupakan lokasi awal dan proses wawancara dengan masyarakat setempat. Dari wawancara diketahui jika pemanfaatan embung selama ini belum dilakukan secara produktif. Pemanfaatan embung sebagai budidaya ikan juga sangat kurang maksimal, sehingga muncul gagasan pemanfaatan embung untuk budidaya ikan tawar menggunakan KJA. Gambar 3(b) menampilkan foto lokasi embung yang belum dimanfaatkan. Dari kondisi tersebut terlihat dimana embung dengan tanaman enceng gondok yang cukup banyak dan tidak dimanfaatkan oleh masyarakat sekitar. Rencana penempatan KJA terletak pada sisi kiri bagian embung hilir yang ditunjukan pada Gambar 3(b) dengan tanda merah. KJA yang didesain juga tidak akan mempengaruhi suplai air untuk irigasi, sehingga pembuatan KJA memang sesuai dengan kebutuhan masyrakat.

\section{Desain keramba Jaring Apung (KJA)}

Detail rencana ukuran KJA diberikan pada Gambar 4. Struktur KJA terdiri dari material baja ringan siku $5 \times 5$ yang membentuk persegi panjang dengan ukuran $4,5 \mathrm{~m}$ dan $3.75 \mathrm{~m}$. Bahan untuk membuat KJA mengapung di air menggunakan drum dengan ukuran $75 \mathrm{~cm}$. Drum tersebut diletakan di bawah struktur penyangga jaring. Ada 2 keramba jarring yang 
direncanakan untuk embung Desa Banaran, kedua KJA tersebut berhimpit dan diletakkan secara proporsional pada embung.

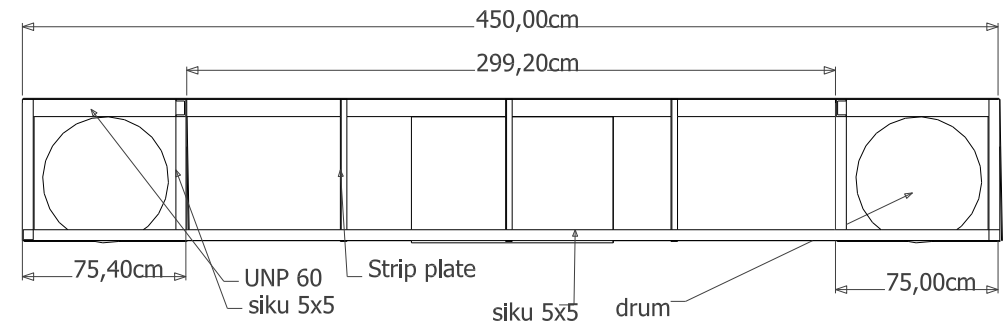

(a)

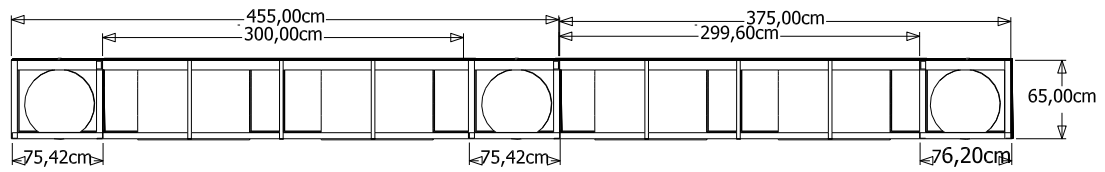

(b)

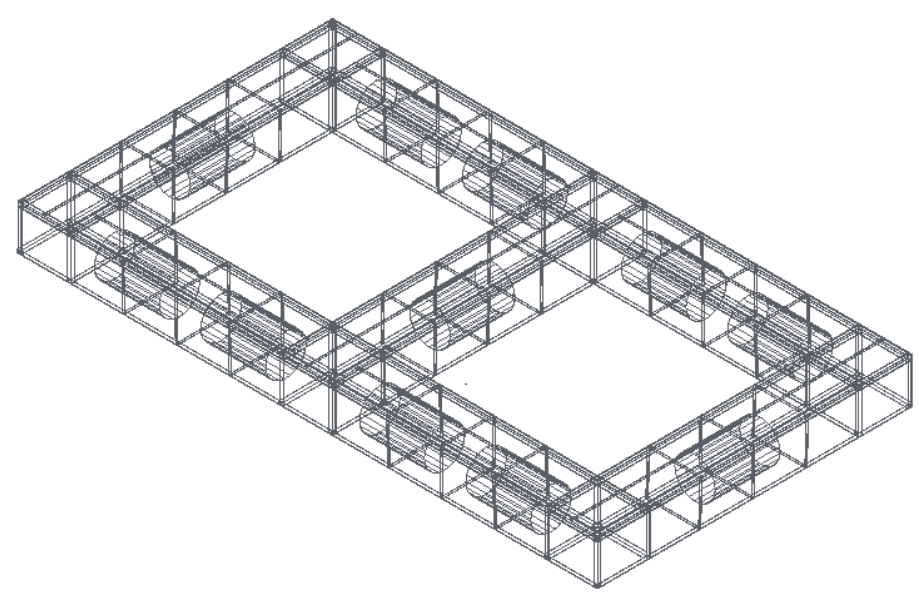

(c)

Gambar 4. Desain KJA (a) Detail KJA 1; (b) Detail KJA gabungan; (c) KJA 3D desain gabungan

\section{Perakitan KJA dan Instalasi di Lapangan}

Perakitan KJA dilakukan setelah proses diskusi dan desain dari tim pengabdian masyarakat. Perakitan KJA menggunakan bahan dari plat baja siku yang disatukan dengan las. Pengelasan dilakukan di Laboratorium Mekanika Tanah Universitas Sebelas Maret, Surakarta. Perakitan yang dilaksanakan diberikan pada Gambar 5a.

Gambar 5a mendeskripsikan desain KJA yang sudah jadi dan akan dibawa ke Embung. Ketika sampai di Bendung maka tim pengabdian dibantu dengan masyarakat melakukan instalasi KJA pada embung seperti ditunjukan pada Gambar 5b. Instalasi drum diletakkan pada keramba untuk membuat keramba bisa terapung. Sebelumnya pihak masyarakat setempat diminta untuk bersama membantu membersihkan area embung dari tanaman enceng gondok. 


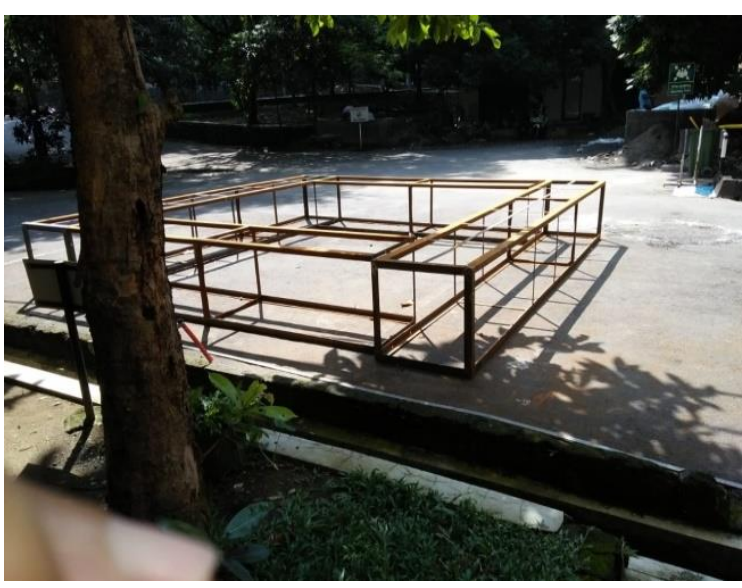

(a)

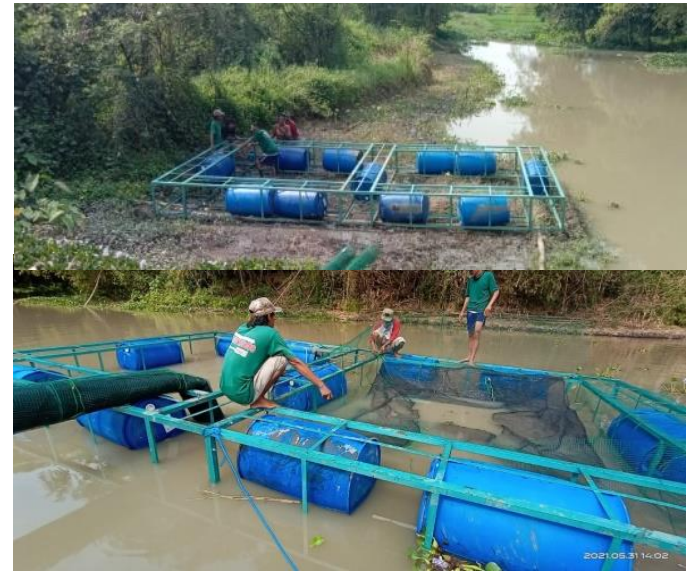

(b)

Gambar 5. Pembuatan KJA dan instalasi (a) Desain setelah jadi; (b)Instalasi KJA pada embung

\section{Penebaran Benih Ikan}

Kegiatan selanjutnya yang dilakukan setelah instalasi keramba adalah penebaran benih oleh semua tim. Benih disebarkan pada kedua KJA dengan jumlah benih yang berbeda. Benih ikan yang akan dibudidaya adalah benih ikan nila. KJA pada budidaya ikan laut sukses dengan budidaya ikan kakap putih (Windarto et al. 2019) atau ikan kerapu (Anhar, Widigdo, and Sutrisno 2020). Sedangkan Pemilihan budidaya ikan nila pada KJA Embung Banaran didasari oleh kisah sukses penggunaan $\mathrm{KJA}$ dengan benih ikan nila pada lokasi tampungan alami seperti Danau Maninjau (Syandri, Azrita, Niagara, 2016), serta tampungan buatan pada tampungan bekas tambang pasir Kelurahan Kalumemeaan (Sambu \& Amir 2017)

Penebaran bibit pada kolam A sebanyak 840 ekor benih ikan, sedangkan untuk kolam B sebanyak 700 benih ikan. Setiap hari jumlah ikan dikontrol berapa yang mati serta berapa berat benih ikan tersebut. Selain itu, kontrol ini digunakan juga untuk perhitungan jumlah pakan dari benih yang sudah disebarkan. Kontrol masih dilakukan secara manual. Namun sebenarnya teknologi terbaru kontrol budidaya ikan pada KJA sudah bisa dilakukan secara otomatis menggunakan system web dengan tinjauan $\mathrm{PH}$ air di $\mathrm{KJA}$ seperti yang dilakukan oleh Muhammad, Muid, \& Triyanto (2016). Kegiatan pengabdian masyarakat ini juga belum membahas bagaimana menjamin kualitas air pada embung seperti yang telah dilakukan oleh Astuti, Hendrawan, \& Krismono (2018). KJA buatan terbaru dengan sistem smart dapat membuat kualitas air pada embung juga dapat dipastikan akan baik.

Jumlah kematian benih ikan selama 2 minggu pertama diberikan pada Gambar 7. Perhitungan kebutuhan pakan diambil 3\% dari berat rata-rata ikan yang hidup. Dari Gambar 7 diketahui bahwa kolam mempunyai jumlah ikan yang lebih banyak kematian dari pada Kolam B. Semakin hari terlihat jumlah kematian ikan semakin berkurang, hal ini disebabkan ikan sudah beradaptasi dengan lingkungan yang baru. Selain itu juga tim memberikan suplemen serta menjaga kualitas air embung lebih terjaga agar ikan dapat berkembang dengan baik. Karena menurut Burhanuddin et al. (2021), salah satu faktor penyebab sedikitnya produksi dan perkembangan budidaya ikan adalah kurangnya nutrisi. 


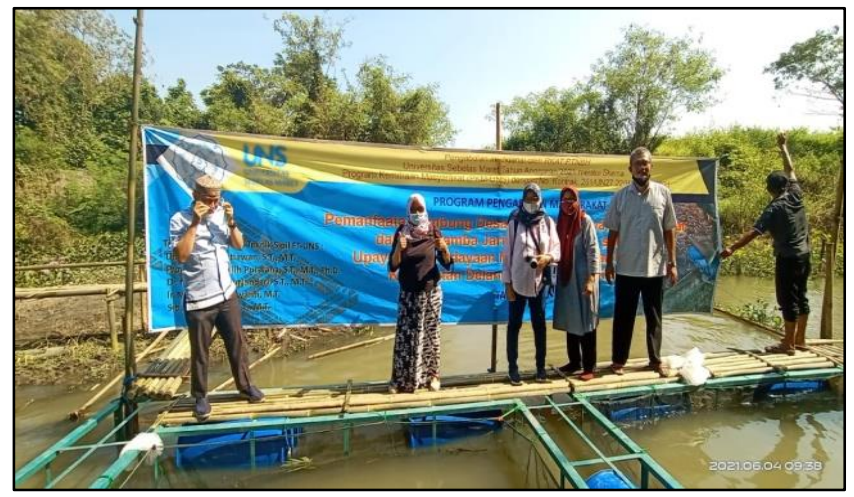

Gambar 6. Penebaran benih ikan
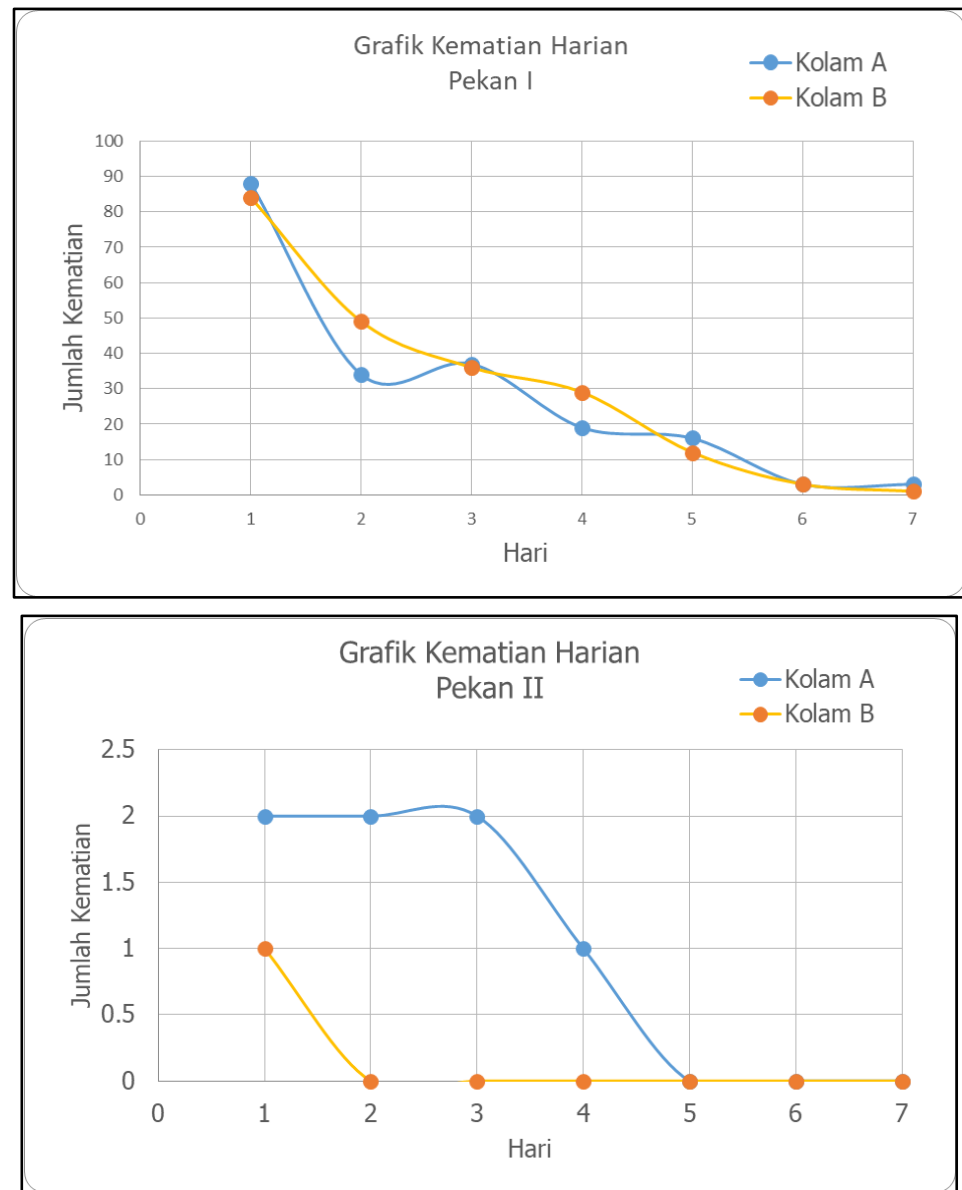

Gambar 7. Kontrol benih Ikan pada KJA

\section{Sosialiasi KJA kepada masyarakat Desa}

Kegiatan selanjutnya yaitu pemberian paparan tentang pemanfaatan embung untuk budidaya ikan tawar melalui sosialisasi sebagaimana pada Gambar 8. Ketika proses sosialisasi berlangsung, terjadi diskusi dua arah antara tim dengan masyarakat. Selama ini masyarakat Desa Banaran belum memahami bagaimana pemberian pakan yang baik. Selama ini pakan ikan dan benih ikan hanya langsung disebar ke seluruh luasan daerah embung tanpa ada perhitungan secara seksama. Selain itu, masyarakat juga belum mengetahui penanggulangan penyakit pada budidaya ikan tawar secara baik dan sistematis. Melalui sosialisasi ini diberikan 
transfer ilmu dari pihak tim ke masyarakat Desa Banaran demi mensukseskan kegiatan pembuatan KJA.
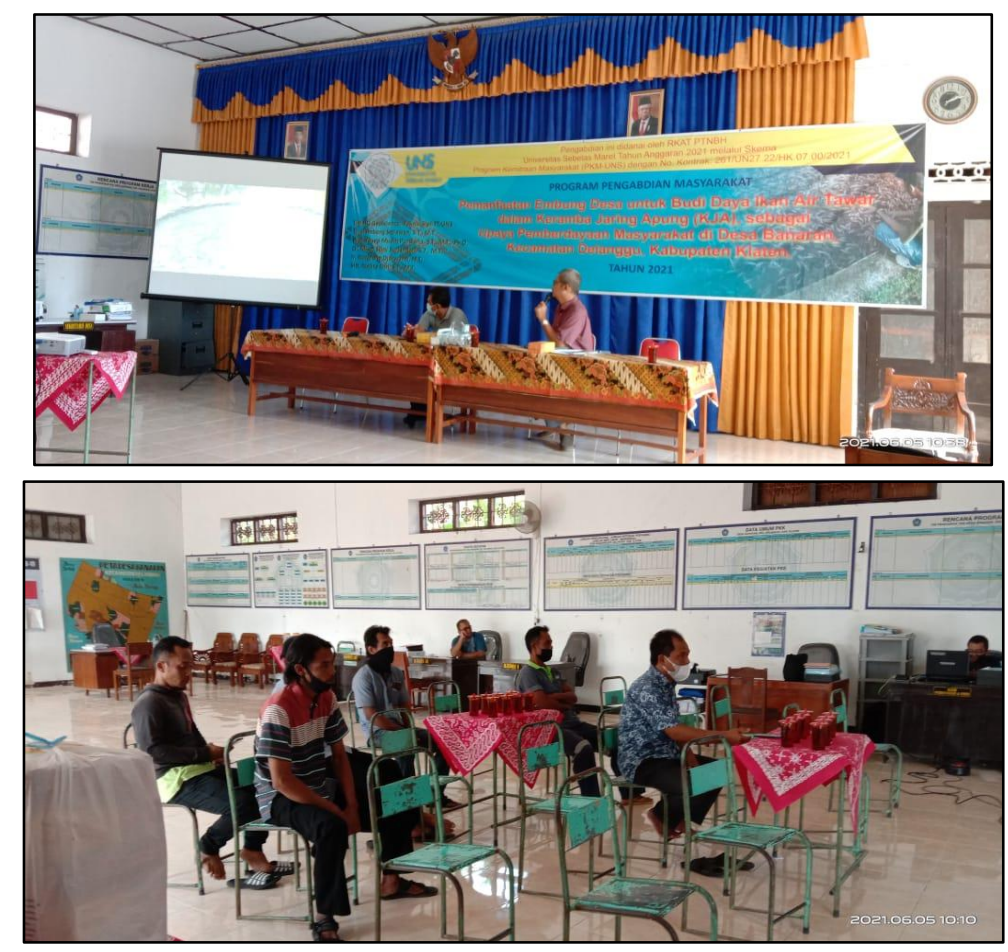

Gambar 8. Sosialiasi KJA Desa Banaran

\section{Kesimpulan}

Kegiatan pengabdian masyarakat dengan pembuatan KJA pada Embung Desa Banaran memberikan efek positif bagi masyarakat. Selain memberikan stimulan berupa alat instalasi KJA, benih ikan nila juga diberikan beserta jumlah pakan yang dibutuhkan. Budidaya ikan yang dihasilkan juga dapat langsung dimanfaatkan oleh masyarakat. Hasil kontrol terlihat bahwa kematian benih ikan diawal memang berlangsung banyak, namun mulai stabil dalam mingu ke 6. Usaha yang perlu dilakukan untuk mencegah kematian diawal penebaran benih adalah mengecek suhu serta memastikan $\mathrm{pH}$ air sesuai dengan rekomendasi dalam budi daya ikan air tawar. Masyarakat sangat antusias dengan pembuatan KJA ini. Terbukti ketika kegiatan penyuluhan berlangsung, banyak yang berdiskusi dan tertarik untuk mengetahui budidaya ikan tawar dengan $\mathrm{KJA}$ seperti cara pemberian pakan dan perhitungan, serta sharing tentang penyakit pada budidaya ikan tawar dengan KJA.

\section{Ucapan Terima Kasih}

Penulis mengucapkan terima kasih kepada LPPM Universitas Sebalas Maret karena Pengabdian masyarakat ini berjalan dengan Hibah NON APBN UNS nomor 261/UN27.22/HK.07.00/2021 pada tahun 2021. 
Setiawan, B., Purwana Y.M., Djarwanti, N., Surjandari, N.S., Fitri, S.N. Pemberdayaan masyarakat desa...

\section{Referensi}

Anhar, T. F., Widigdo, B., \& Sutrisno, D. (2020). Kesesuaian budidaya keramba jaring apung (KJA) ikan kerapu di perairan Teluk Sabang Pulau Weh, Aceh. DEPIK Jurnal IImu-IImu Perairan, Pesisir dan Perikanan, 9(2), 210-219. https://doi.org/10.13170/depik.9.2.15199

Ardi, I. (2013). Budidaya ikan sistem keramba jaring apung guna menjaga keberlanjutan lingkungan perairan waduk cirata. Media Akuakultur, 8(1), 23-30. http://dx.doi.org/10.15578/ma.8.1.2013.23-29

Astuti, L. P., \& Krismono, K. (2018). Pengelolaan kualitas perairan melalui penerapan budidaya ikan dalam keramba jaring apung "SMART". Jurnal Kebijakan Perikanan Indonesia, 10(2), 87-97. http://dx.doi.org/10.15578/jkpi.10.2.2018.87-97

Burhanuddin, B., Anwar, A., Khaeriyah, A., Akmaluddin, A., Arwati, S., Ikbal, M., \& Hamsah, H. (2021). Meningkatkan Pemahamanan Pembuatan Pakan Ikan Pada Anggota Kelompok Jenber Sistem Keramba Jaring Apung di Kelurahan Tanjung Merdeka, Kota Makassar. To Maega: Jurnal Pengabdian Masyarakat, 4(1), 26-34. http://dx.doi.org/10.35914/tomaega.v4i1.434

Dangnga, M. S., Halimah, A. S., \& Asniar, A. (2019). Dampak Pembangunan Embung Bagi Usaha Tani Padi Sawah Tadah Hujan. Galung Tropika, 8(3), 224-234.

Hidayati, B. N., Darsono, D., \& Barokah, U. (2020). ANALISIS USAHA BUDI DAYA IKAN NILA MENGGUNAKAN KERAMBA JARING APUNG (KJA) DAN PEMASARANNYA DI KABUPATEN SRAGEN. Buletin IImiah Marina Sosial Ekonomi Kelautan dan Perikanan, 6(2), 145-157. http://dx.doi.org/10.15578/marina.v6i2.8233

Muhammad, S., Muid, A., \& Triyanto, D. (2016). Rancang Bangun Sistem Pemberi Pakan Ikan Dan Pengukur Ph Air Pada Keramba Berbasis Website. Coding Jurnal Komputer dan Aplikasi, 4(2).

Rahmadana, A. (2013). Studi Pengaturan Air Untuk Meningkatkan Kinerja Waduk Batutegi. Tesis Magister Pengelolaan Air dan Air Limbah, Program Pascasarjana, Fakultas Teknik, Universitas Gadjah Mada.

Rahman, Latief, M., Nursari, E., \& Baskoro, D. P. T. B., (2019). Pengaruh Embung Dan Kombinasinya Dengan Teknik Konservasi Tanah Dan Air Lainnya Terhadap Koefisien Regim Aliran Dan Koefisien Aliran Tahunan. Jurnal Geografi Lingkungan Tropik, 2(2), 113. http://dx.doi.org/10.7454/jglitrop.v2i2.45

Rustam, R. K. (2010). Tata Ruang Air . CV. Andi.

Sambu, A. H., dan Amir, D.A., (2017). Budidaya Ikan Nila Dengan Sistem Keramba Jaring Apung. OCTOPUS Jurnal IImu Perikanan 6(1), 546-550.

Syandri, H., Azrita., Niagara. (2016). Trophic Status and Load Capacity of Water Pollution Waste Fish Culture with Floating Net Cages in Maninjau Lake, Indonesia. Eco. Env. \& Cons. 22 (1).

Windarto, S., Hastuti, S., Subandiyono, S., Nugroho, R. A., \& Sarjito, S. (2019). Performa pertumbuhan ikan kakap putih (lates calcarifer bloch, 1790) yang dibudidayakan dengan sistem Keramba Jaring Apung (KJA). Sains Akuakultur Tropis: Indonesian Journal of Tropical Aquaculture, 3(1). 56-60. https://doi.org/10.14710/sat.v3i1.4195 